\title{
Predicting erosion and sediment yield in a mesoscale basin in the semiarid monsoon region Miyun/China
}

\author{
Michael Gebel ${ }^{1 *}$, Mario Uhlig ${ }^{1}$, Stefan Halbfass ${ }^{1}$, Ralph Meissner ${ }^{2}$ and Shuhuai Duan ${ }^{3}$
}

\begin{abstract}
Introduction: Changes in land use and agricultural management have caused a strong increase in sediment and particulate phosphorus input into the Miyun reservoir. The simulation of the relevant runoff and sediment fluxes at the mesoscale needs adequate procedures, adapted to a semiarid monsoon climate and regional land-use pattern.

Results: The modified Universal Soil Loss Equation (USLE-M) was integrated into the STOFFBILANZ model to calculate daily soil losses in the entire Miyun catchment area. The results are well within the range of monitoring data from Wischmeier plots that are located inside the investigation area. For the reference year 2009, soil erosion was estimated at an average of $952 \mathrm{~kg} \mathrm{ha}^{-1}$ year $^{-1}$. Daily based simulation of sediment input into surface waters was done in the next step, taking into account the likeliness of sediment input and sediment delivery ratio. Average sediment inputs are by $113 \mathrm{~kg} \mathrm{ha}^{-1}$ year $^{-1}$. Critical source areas are located on cropland and are particularly relevant on the former lakebed of the Miyun reservoir which has recently been used for corn cropping.

Conclusions: Compared with observation data from the Bai and Chao rivers, the simulation of sediment loads showed a satisfying agreement that underlines the suitability of the selected approach to substitute recently used one-year balances based on the Universal Soil Loss Equation (USLE) approach. Conservation tillage was selected as a possible mitigation option to reduce soil erosion and sediment loads.

Owing to the limited availability of spatial and monitoring data, the simulations are approximate and only a first step in contributing to an integrated river basin management that should be improved in future.
\end{abstract}

Keywords: Direct runoff; Mesoscale; Miyun; Model; Sediment input; Soil erosion; STOFFBILANZ

\section{Introduction}

The Miyun reservoir, located approximately $100 \mathrm{~km}$ in the northeast of the Beijing municipality, is one of the most important surface water supply sources for the 20 million people living in the metropolitan area. Changes in land use and agricultural management during past decades are the main reasons for a strong increase in sediment, nitrogen, and phosphorus input into the reservoir, causing water quality problems (Peisert and Sternfeld 2004; $\mathrm{Ou}$ and Wang 2008). Long-term droughts and sediment delivery through debris flows, as well as fish pond economy and tourism are additional stressors for

\footnotetext{
* Correspondence: gebel@galf-dresden.de

${ }^{1}$ Gesellschaft für Angewandte Landschaftsforschung (GALF) bR, Am Ende 14, 01277 Dresden, Germany

Full list of author information is available at the end of the article
}

water quality and quantity (Peisert and Sternfeld 2004; Tao et al. 2005; Wang 2006; Cai 2008; Ma et al. 2010).

Mitigation options for the nitrogen and phosphorus pollution have to be strongly promoted on both local and regional scales. To fulfil these requirements within the framework of the joint German-Chinese research project 'Development and implementation of a scientifically based management system for non-point-source pollution control in the Miyun basin', a scaled monitoring approach was installed to obtain insight into runoff generation processes and sediment and nutrient transfer $d y-$ namics. This approach was accomplished by a process-based modelling with the hydrological model WaSim-ETH/IWAN (Ollesch et al. 2006) in small sub-catchments (Meissner et al. 2011; Meissner and Hagenau 2013). Based on these investigations, Web GIS-based software STOFFBILANZ (Gebel $e t$ al. 2012a) was used to simulate runoff (Allen et al. 1998; 
NRCS 2004; Hawkins et al. 2009), soil erosion (Kinnell 2001), sediment and nutrient input in the whole catchment area for the current situation as well as to check the effectiveness of mitigation options.

Integrative planning and management in larger areas, as intended by the EU Water Framework Directive (EU 2000), as well as 'soft' approaches, such as the ecosystem services concept (Alcamo et al. 2003), have only just begun in the region. Sectoral approaches and large-scale investigations are actually much more common for the regulation of runoff and water quality, soil conservation, soil fertility and food production.

The objectives of this paper are, first, to simulate soil erosion and sediment input in the entire Miyun catchment area on a daily basis, taking into account the extremely episodic rainfall, and, second, to show recent modelling options and limits as part of integrated river basin management in the study area.

The described methods were mainly used for state-ofthe-art and scenario impact analyses and decision support in the planning process, and were utilized by the Beijing Water Authority (BWA), which is the main stakeholder for water affairs in the region. The BWA has representatives in rural communities and is a multiplier for knowledge transfer and implementation of project results.

\section{Study area and data}

The area of the Miyun catchment, with a total extent of $15,654 \mathrm{~km}^{2}$, is part of the provinces Beijing and Hebei, bordering the Mongolian Plateau in the northern parts of China. At the county level, Miyun, Chicheng, Fengning, Huairou and Luanping have the biggest shares of the total catchment area (Table 1).
Owing to limitations of data availability by government authorities, freely available spatial data $(30 \times 30 \mathrm{~m}$ ASTER DEM, $30 \times 30 \mathrm{~m}$ Landsat TM, Harmonized World Soil Database (FAO/IIASA/ISRIC/ISS-CAS/JRC 2009, combined with a digital soil mapping procedure) were mainly used to get information about the basic landscape pattern. Necessary daily meteorological and atmospheric data were disaggregated from mean monthly WorldClim datasets (1960 to $1990,1,000 \times 1,000 \mathrm{~m}$ : WorldClim 2013, Hijmans et al. 2005) combined with daily information from selected weather stations for one particular year (2009). These data were integrated into a grid with variable cell size $(125 \times$ $125 \mathrm{~m}$ up to $500 \times 500 \mathrm{~m}$; approximately 366,000 grid cells). Cropland and residential areas were set to the highest resolution, to optimize the indication of critical source areas.

The major part of the Miyun catchment area, with altitudes ranging from 60 to 2,200 $\mathrm{m}$ above sea level, is mountainous with steep inclinations. Annual average precipitation in the semiarid continental monsoon climate is less than $500 \mathrm{~mm}_{\text {year }}^{-1}$ and occurs mainly in summer, whereas winter and spring are extremely dry (Chen et al. 2011a). Precipitation increases from east to west, and annual average temperature increases from southeast to northwest, ranging from 6.3 to $10.9^{\circ} \mathrm{C}$. Land cover is dominated by rocky mountain forest (54.8\%), with a smooth transition to shrubbery, heath and dry grassland (31.5\%). Cropland (10.7\%) can be found mainly in the valleys and intramountainous basins on terraced ground (Figure 1), carrying fertile soils into quaternary sediments (e.g. loess), but also on the dry bottoms of the Miyun reservoir. The water level of this reservoir is continually decreasing, caused by droughts in the last twenty years.

Table 1 Soil loss, likeliness of connectivity and sediment input in counties (reference year 2009)

\begin{tabular}{|c|c|c|c|c|c|c|}
\hline \multirow[t]{2}{*}{ County } & \multirow[t]{2}{*}{ Percentage share } & \multicolumn{2}{|l|}{ Soil loss } & \multirow{2}{*}{$\begin{array}{l}\text { Likeliness of connectivity } \\
\text { Average }\end{array}$} & \multicolumn{2}{|l|}{ Sediment input } \\
\hline & & Average kg ha ${ }^{-1}$ & Sum kg & & Average kg ha ${ }^{-1}$ & Sum kg \\
\hline Chengde Xiàn & $<0.1$ & 15 & 45,710 & 0.064 & 0.4 & 1,372 \\
\hline Chicheng & 33.3 & 853 & $447,495,211$ & 0.086 & 96.2 & $50,489,563$ \\
\hline Chongli & 0.7 & 1,078 & $13,325,848$ & 0.075 & 113.0 & $1,397,734$ \\
\hline Fengning & 26.5 & 1,124 & $475,147,313$ & 0.083 & 144.3 & $60,982,260$ \\
\hline Guyuan & 3.2 & 835 & $37,127,947$ & 0.089 & 68.7 & $3,057,593$ \\
\hline Huailai & $<0.1$ & 543 & $1,142,184$ & 0.064 & 29.3 & 61,590 \\
\hline Huairou & 8.2 & 507 & $65,954,033$ & 0.084 & 76.8 & $9,978,605$ \\
\hline Luanping & 9.2 & 1,002 & $145,979,770$ & 0.088 & 135.9 & $19,811,394$ \\
\hline Miyun & 9.3 & 1,503 & $221,137,925$ & 0.081 & 150.4 & $22,129,705$ \\
\hline Xinglong & 3.0 & 401 & $19,975,330$ & 0.076 & 25.0 & $1,246,885$ \\
\hline Xuanhua & $<0.1$ & 348 & $1,088,981$ & 0.043 & 10.0 & 31,162 \\
\hline Yanqing & 6.4 & 355 & $27,606,481$ & 0.086 & 45.4 & $3,525,090$ \\
\hline Sum & 100 & & $1,456,026,733$ & & & $172,712,953$ \\
\hline
\end{tabular}




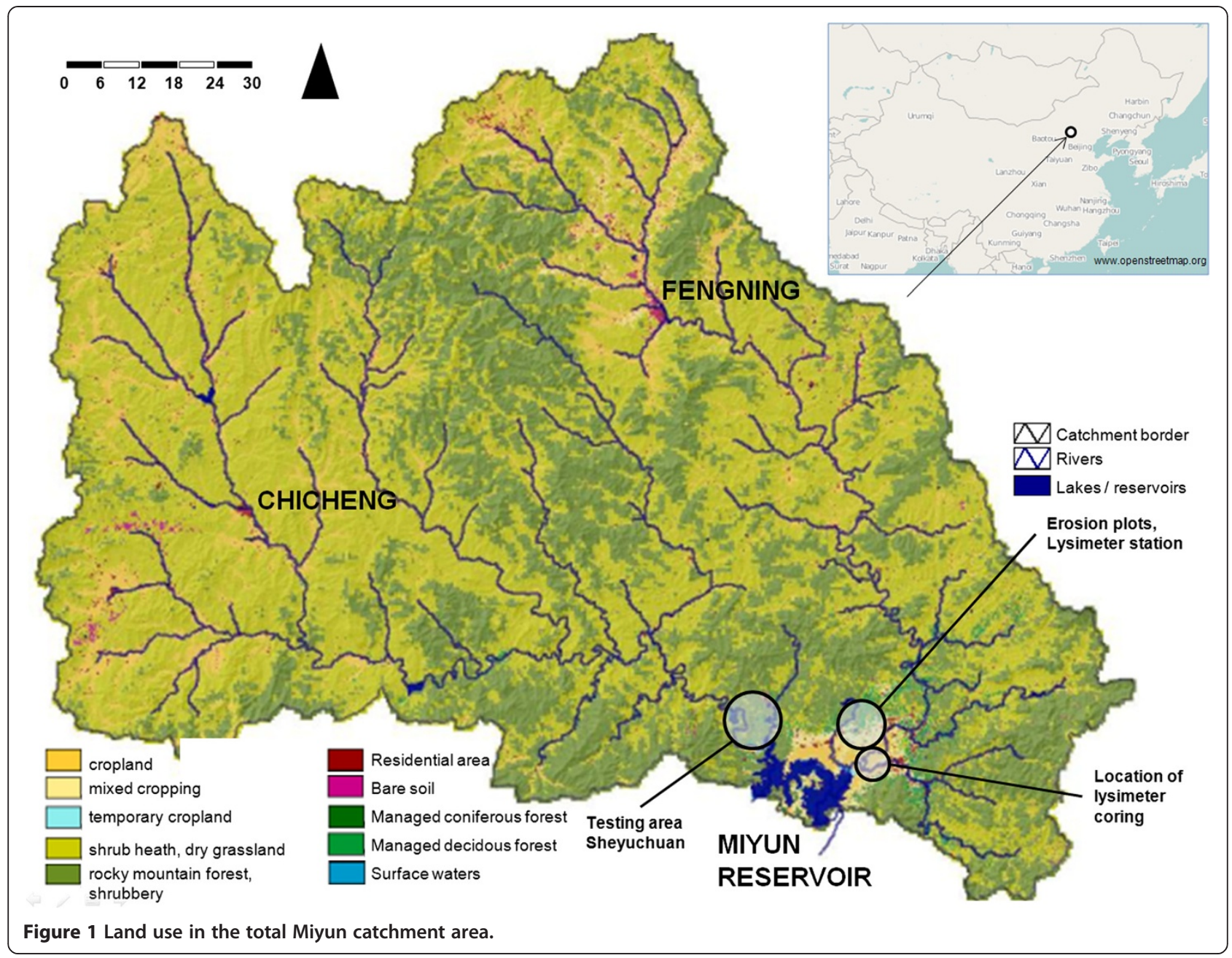

According to Zhou et al. (2010), cropland in the counties of Chicheng, Fengning and Luanping (reference year 2005 ) is about $8.1 \%$, which is close to the $9.2 \%$ value for the same region processed by our remote sensing in the study area. In the total catchment area, cropland is about $10.7 \%$. Residential areas have a share of $1 \%$. Economic deciduous and coniferous forests have a share of approximately $1 \%$. Bare soils and wasteland (mining areas) are about $0.1 \%$, surface waters are about $0.5 \%$. Parameters of agricultural management were taken from the China Statistical yearbooks. Major crops planted recently are corn (59\%) and vegetables (16\%).

According to the typology of the Harmonized World Soil Database (FAO/IIASA/ISRIC/ISS-CAS/JRC 2009) there is a mixture of Fluvisols, Luvisols, Cambisols and Kastanozems/Greysems in flat or hilly areas, whereas the mountainous area is mainly covered by Leptosols. The soil information is based on the Food and Agriculture Organization (FAO) soil map combined with a terrain analyses to exclude natural vegetation areas, which are not significantly represented in the FAO map. Our experiences from the field trip showed that these areas are mainly covered by Leptosols.

\section{Methods}

The Web GIS-based software STOFFBILANZ (Gebel et al. 2010, 2012a,b) was used to calculate runoff, soil loss, sediment and nutrient input in the whole catchment area (variable grid size from $125 \mathrm{~m} \times 125 \mathrm{~m}$ to $500 \mathrm{~m} \times 500 \mathrm{~m}$ ). The approach requires a minimal number of parameters to run the model and is suitable for modelling on regional scale. To guarantee a sufficient resolution in time and space in the semiarid monsoon region, a daily based calculation was realized for the following parameters:

- Evapotranspiration and deep percolation under soil water stress conditions (Allen et al. 1998; Gebel et al. 2014),

- Surface runoff according to the Curve Number approach (NRCS 2004; Hawkins et al. 2009; Gebel et al. 2014), 
- Amount of soil erosion according to the modified Universal Soil Loss Equation (USLE-M) approach (Kinnell 2001; Yu and Rosewell 1996),

- Amount of sediment input (Voges 1999; Veith 2002; Halbfass 2005; Halbfass and Grunewald 2008),

- Runoff at the different scales (Gebel et al. 2014).

Calibration and testing of the runoff modelling was done on the basis of the continual monitoring at an installed lysimeter station (plot scale) and hydrological measurements in small sub-catchments (microscale) in a bottom-up approach (Meissner and Hagenau 2013). In summary, it could be shown that the model was also able to give sufficient information about runoff generation and water fluxes at the mesoscale. A detailed description of this work is given elsewhere (Gebel et al. 2014).

\section{Meteorological data disaggregation for the total catchment area}

Grid-based climate data were only given as monthly long-term average values from the WorldClim dataset (WorldClim 1960 to $1990,1 \mathrm{~km}^{2}$ ). To generate a daily distribution of temperature and precipitation values, the monthly WorldClim data (Hijmans et al. 2005) were combined with a daily distribution from a given meteorological station in the central part of Miyun catchment area for the reference year 2009. Thus, it was possible to consider the runoff events at a daily resolution, whenever the monthly sum of precipitation corresponded to the long-term WorldClim dataset. Daily meteorological data are the result of this disaggregation and do not correspond directly to observed values in detail. If real values are available in the future, they should be used instead of the modelled ones. Nevertheless, it was possible to simulate water fluxes based on these data, which gave an impression of the recent situation regarding runoff at a daily resolution. In our experience, this strategy is absolutely necessary to get reliable results for the typical monsoon climate influenced study area.

\section{Daily soil erosion}

The Universal Soil Loss Equation (USLE, compare with Wischmeier and Smith 1978) is not well suited to the prediction of event erosion in grid cells. Therefore, a daily based modification of the USLE, called the USLE$M$, was used, which can fulfil this task much better (Yu and Rosewell 1996, Kinnell 2001). Soil erosion by storm runoff events $A_{e}$ is calculated as:

$$
A_{e}=R_{e U M} K_{e U M} L S C_{\text {eUM }} P_{e U M}
$$

where:

$R_{\mathrm{eUM}}$, event-based erosivity factor;
$K_{\mathrm{eUM}}$, event-based soil factor;

$L S$, length factor $\times$ slope factor;

$C_{\mathrm{eUM}}$, event-based crop factor;

$P_{\text {eUM }}$, event-based management factor.

The factors $\mathrm{K}_{\mathrm{eUM}}, \mathrm{C}_{\mathrm{eUM}}$ and $\mathrm{P}_{\mathrm{eUM}}$ were calculated as:

$$
\begin{aligned}
K_{\text {eUM }} & =\left(K \times p_{d}\right) / Q_{\text {effal }} \\
C_{\text {eUM }} & =\left(C \times Q_{\text {efal }}\right) / Q_{e} \\
P_{\text {eUM }} & =\left(P \times Q_{\text {effal }}\right) / Q_{e}
\end{aligned}
$$

where:

$K$, soil factor (see Wischmeier and Smith 1978);

C, soil cover by plant (see Allen et al. 1998; Dissmeyer and Foster 1980);

$P, P$-factor (set to 1 );

$p_{\mathrm{d}}$, daily precipitation;

$Q_{\text {e.fal }}$, daily direct runoff on a fallow site;

$Q_{e}$, daily direct runoff.

$C$ requires information about the development stage of vegetation; this was taken from Allen et al. (1998) for tilled cropland (0.01 to 1 ) and Dissmeyer and Foster (1980) for natural vegetation (0.01 to 0.03). $P$ was set to 1 .

A detailed summary of different $R$-factor estimates using monthly precipitation data is given by Renard and Freimund (1994). They estimated the yearly $R$-factor by using the modified Fournier index, which is defined as:

$$
F \frac{\sum_{j=1}^{12} P_{j}^{2}}{P}
$$

where:

$F$, modified Fournier index;

$P$, precipitation per year;

$P_{j}$, precipitation per month.

The modified Fournier index has been used successfully for countries in Africa (Arnoldus 1977), as well as the continental United States (Renard and Freimund 1994) and different southeastern Australian sites ( $\mathrm{Yu}$ and Rosewell 1996). It was selected for the Miyun study area because it takes into account the monthly variation of precipitation, which is extremely important in the continental monsoon climate in the study region. The daily erosivity factor, $R_{\mathrm{eUM}}$, is given by:

$$
R_{e U M}=\frac{0.7397 \cdot F^{1.847}}{P} \cdot P_{d} \cdot \frac{Q_{e}}{P_{e}}
$$

where:

$P_{\mathrm{d}}$, precipitation per day;

$P_{\mathrm{e}}$, rain amount per event;

$Q_{e}$, direct runoff per event.

A more detailed description is given in $\mathrm{Yu}$ and Rosewell (1996) and Kinnell (2001). 
The $L$ and $S$ factors were calculated separately using SAGA GIS software (SAGA 2013).

\section{Daily sediment input}

Only a smaller part of eroded soil will reach the river network, since soil erosion is closely connected to sedimentation. Sediment input into the river network is often limited to a few specific sites in a catchment, but can be very high at those hotspot areas. Approximately $90 \%$ of the sediment input into surface water is supposed to originate from $10 \%$ of a catchment's area (Voges 1999; COST Action 869 2006). Major controlling factors for sediment input into a river network are the intensity of soil erosion, the distance of an erosive site from the watercourse and the transportation capacity of surface runoff (Voges 1999). Empirical models often use the sediment delivery ratio (SDR) to calculate the ratio between soil erosion and sediment input into the river network. In this study, sediment input was estimated by the STOFFBILANZ model, based on findings from Voges (1999), Veith (2002), Halbfass (2005) and Halbfass and Grunewald (2008). In the first step, a GIS-based separation was used to exclude areas with a missing hydraulic connection to the river network (caused by artificial barriers of the flow path, such as roads or railways (compare with Halbfass and Grunewald 2008; Figure 2).

The sediment delivery ratio (SDR) was calculated as:

$$
\mathrm{SDR}=\chi_{i}\left(\frac{S}{l_{\text {flow }}}\right)^{(1-P)}
$$

where:

$X_{i}$, coefficient of land use;

$s$, slope $\left(\mathrm{m} \mathrm{m}^{-1}\right)$;

$l_{\text {flow }}$, average distance from watercourse $(\mathrm{m})$;

$P$, likeliness of connectivity.

The coefficient $X_{i}$ was derived from the daily $C$ factor (according to Gebel et al. 2012a):

$$
X_{i}=1.43 \cdot \ln (C \text { factor })+9.49
$$

The likeliness of connectivity $P$ (day) was calculated using the following square root function according to Voges (1999):

$$
P=\sqrt{p^{2} l_{\text {flow }}+p^{2} A+\mathrm{p}_{R O}^{2}}
$$

where:

$p l_{\text {flow }}$, probability index for the distance to the watercourse;

$p_{\mathrm{A}}$, probability index for soil erosion;

$p_{\text {RO }}$, probability index for surface runoff.

Sediment input into surface waters was calculated as:

$$
S E=S D R \cdot A \cdot a
$$

where SE $\left(\mathrm{t} \mathrm{day}^{-1}\right)$ is the land use specific daily sediment input, $\mathrm{A}\left(\mathrm{t} \mathrm{ha}^{-1} \mathrm{day}^{-1}\right)$ is the daily soil erosion rate and $a$ $(0 \leq a \leq 1)$ is the share of an area where a hydraulic connectivity is given.

\section{Results}

\section{Baseline scenario}

In the following, the focus is on modelling soil erosion and sediment input in the total catchment area. The simulated soil erosion in the total catchment area is shown in Figure 3. Maximum rates are about $84.791 \mathrm{t} \mathrm{ha}^{-1}$ year $^{-1}$ on cropland. The average value for the total catchment area is $931.3 \mathrm{~kg} \mathrm{ha}^{-1}$ year $^{-1}$, corresponding to a sum of $1,456,027 \mathrm{t} \mathrm{year}^{-1}$. Sediment input into waters was simulated with a sum of $172,713 \mathrm{t} \mathrm{year}^{-1}$ and $112.7 \mathrm{~kg}$ $\mathrm{ha}^{-1}$ year $^{-1}$ on average (Figure 4). Maximum rates are about $71,644 \mathrm{~kg} \mathrm{ha}^{-1}$ year $^{-1}$ on cropland, with a high connectivity to the river net. Critical source areas for Miyun reservoir are particularly located on the former lake bed of the Miyun reservoir, which is currently used for the intensive production of corn, and in the larger river valleys of the catchment, with corn cropping. Residential areas were not included in our simulation, because of missing data. According to land-use classification by remote sensing,

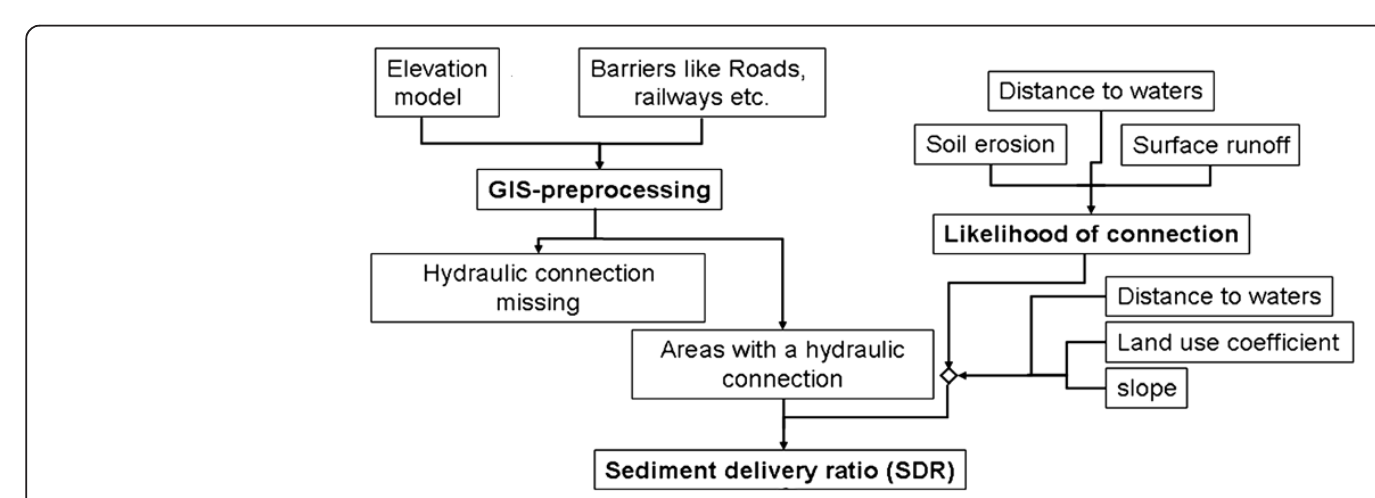

Figure 2 Methodological approach to compute the sediment delivery ratio (SDR). 


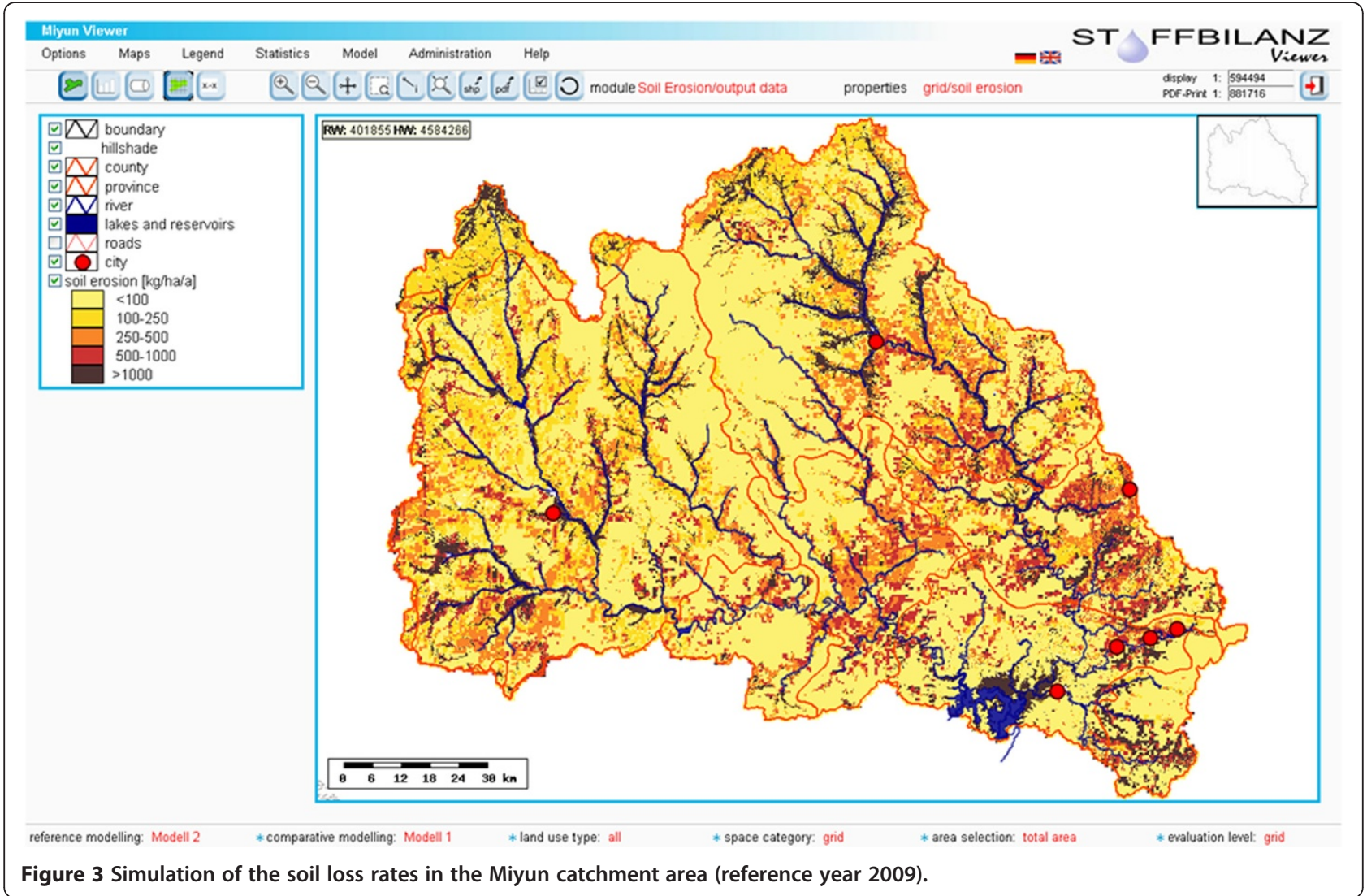

bare soils are mainly located on dry river bottoms and therefore are not relevant for soil erosion. Badlands are more present in the northwestern part of the Miyun catchment area, but are often covered with shrubs. A separate classification of badlands with bare soils was not possible, because the resolution of the grid cells was not small enough.

Average values for soil loss, likeliness of connectivity and sediment input are documented in Table 1 at the county level.

A validation at the sub-catchment scale was not possible, because the necessary information on soil erosion and sediment loads was not available. Alternative observations of soil erosion from Wischmeier plots at Shixia research station (Figure 1) in the southern part of the catchment area for the period 2008 to 2010 could be used to test the plausibility of the uncalibrated soil erosion modelling. According to Figure 5, the simulated soil erosion on cropland and temporary cropland is well in the range of the observations on the cropland plots at Shixia station. We also received a high correlation on mixed cropping (chestnut trees combined with an annual crop) and forest sites (compared with 'natural'), as well as on shrub heath (compared with hawthorn). An underestimate could be relevant for the northwestern part of the catchment area, especially for natural vegetation (shrub heath or secondary forests), because the density of vegetation is probably lower than supposed. The observations from Shixia station might represent the western part situation more adequately.

Simulated and observed soil erosion in the total catchment area is determined absolutely by soil losses on cropland, mainly covered with corn (average soil loss on cropland: $8.2 \mathrm{t} \mathrm{ha}^{-1}$ year $^{-1}$, maximum value: $84.8 \mathrm{t} \mathrm{ha}^{-1}$ year $^{-1}$ ). The chestnut trees (if combined with an annual crop, such as corn or peanuts), forest and shrub heath or dry grassland, with their higher soil cover, are much better protected against soil erosion.

From the monitoring data available for the Chao River $\left(9,558 \mathrm{~km}^{2}\right)$ and Bai River $\left(6,230 \mathrm{~km}^{2}\right)$ of the Chinese partner BWA, the average sediment inputs in the time period 2000 to 2005 are about $78 \mathrm{~kg} \mathrm{ha}^{-1}$ year $^{-1}\left(123,012 \mathrm{t} \mathrm{year}^{-1}\right)$. The observations show that sediment input is extremely episodic and there is a wide range between different years, caused by differences in the timing, intensity and amount of rainfall (for example, Chao River: maximum value for sediment input, $861 \mathrm{~kg} \mathrm{ha}^{-1}$ year $^{-1}$ in 2001; standard deviation of sediment input into the Chao River from 2000 to 2005, $340 \mathrm{~kg} \mathrm{ha}^{-1}$ year $^{-1}$; average sediment input from 2000 to $2005,173 \mathrm{~kg} \mathrm{ha}^{-1}$ year $^{-1}$ ). According to this, the simulated sediment input of $113 \mathrm{~kg} \mathrm{ha}^{-1}$ year $^{-1}$ $\left(172,713 \mathrm{t} \mathrm{year}^{-1}\right)$ is in the range of the observed one. 

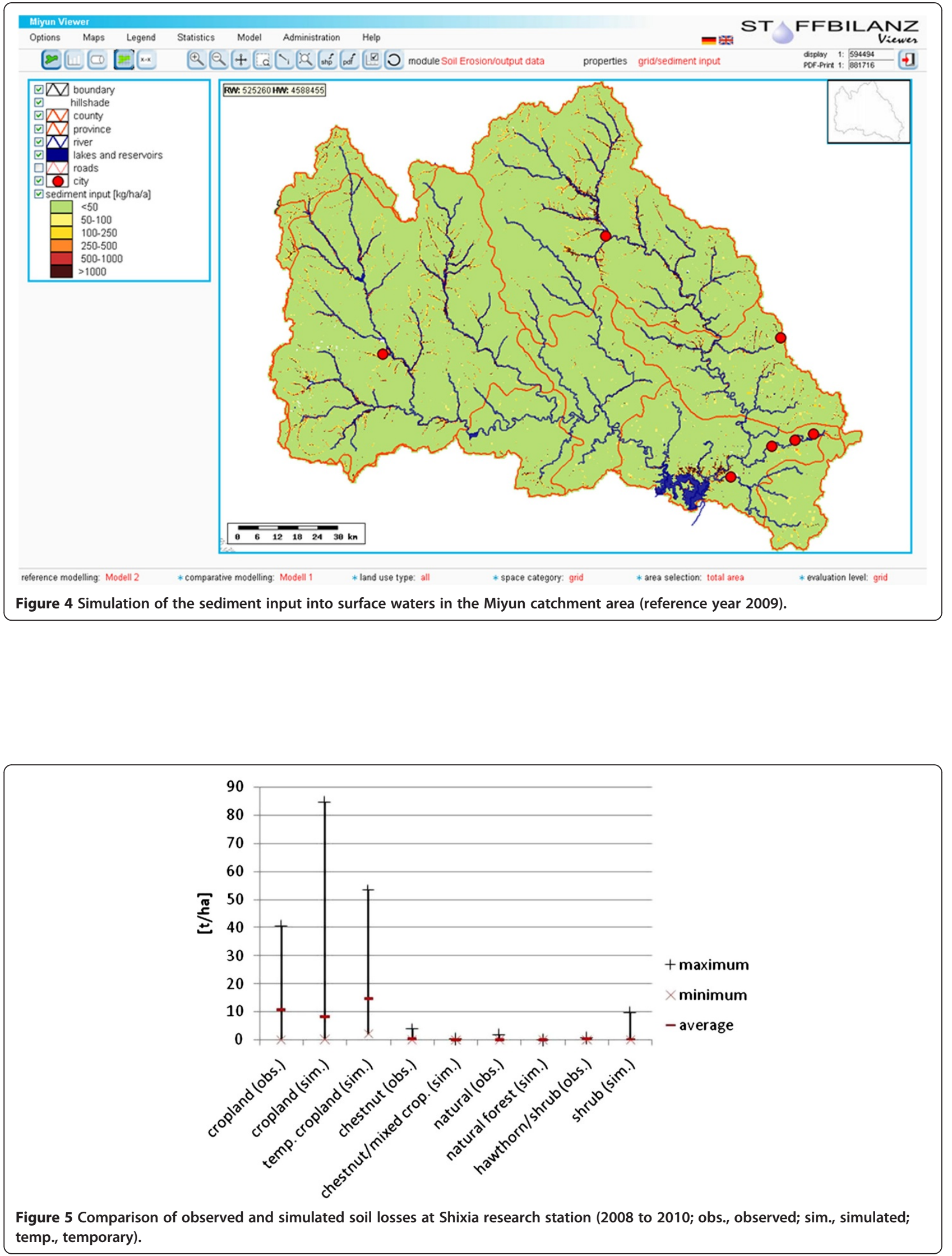

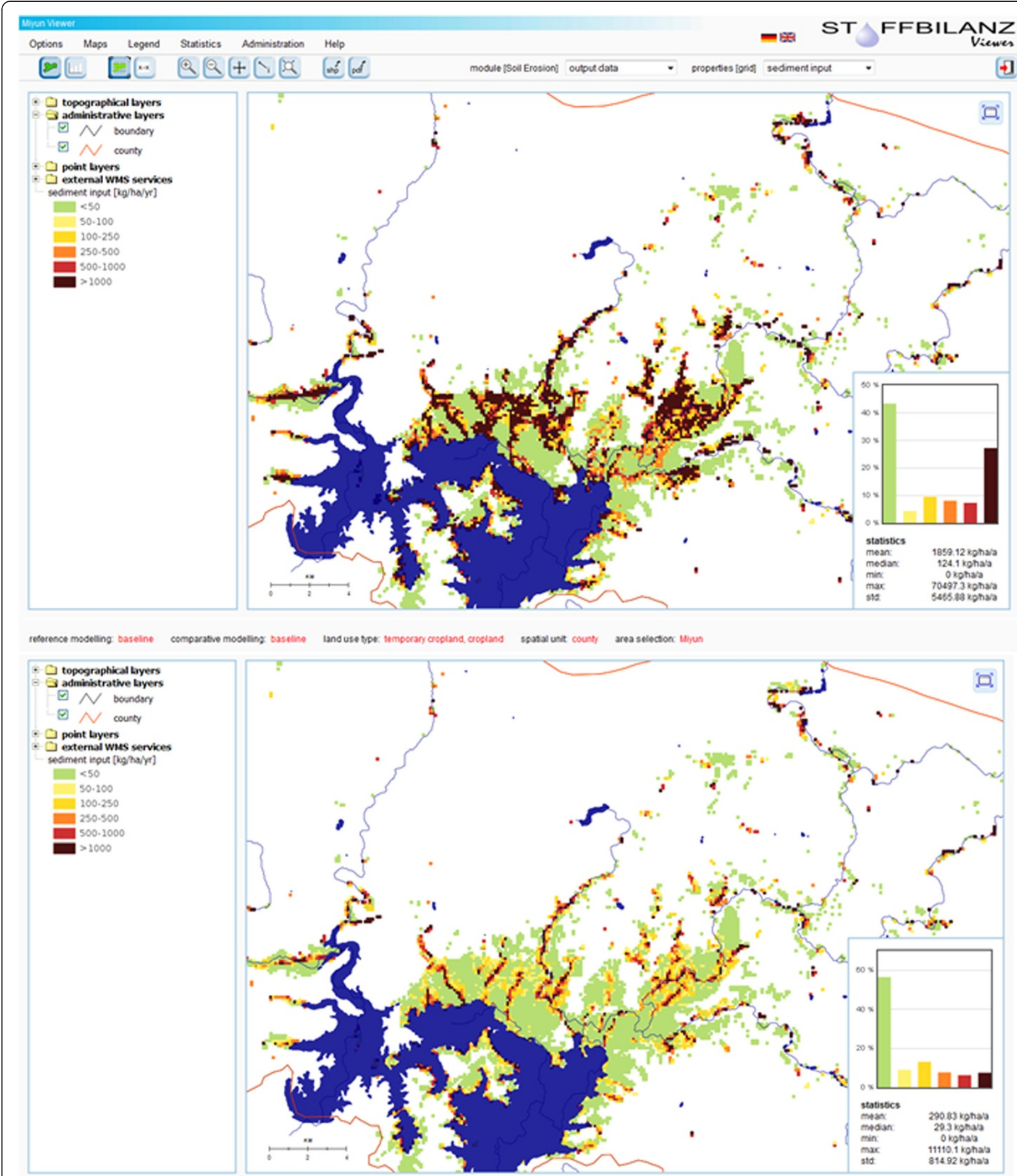

Figure 6 Sediment input in surface waters in Miyun County from cropland for the baseline scenario and the 'no-tillage' scenario (2009).

\section{Mitigation scenario 'no-tillage'}

The results of the baseline scenario underline that critical source areas are particularly located on cropland with a special focus on the former lakebed of the Miyun reservoir, which is actually used for intensive corn cropping. In Europe, conservation tillage is a well-known 


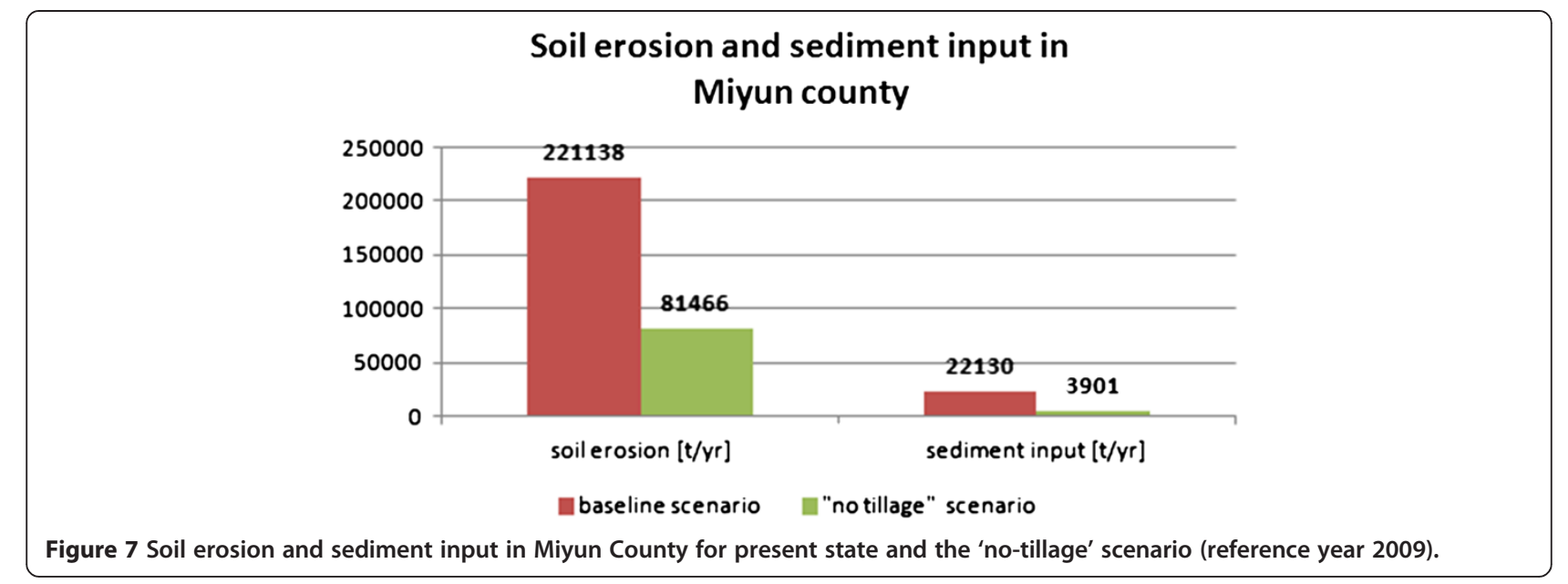

option to reduce soil erosion and sediment input in water courses. The effectiveness of this mitigation option was simulated for Miyun County, located in the southeastern part of the Miyun catchment area. It was supposed that conservation tillage will be established on $100 \%$ of all cropland in Miyun County that is not terraced. This limitation was necessary, because a no-tillage practice needs machinery that cannot be used on terraces for technical restrictions. To consider the no-tillage practice in the model, the $C$ factor on such areas was limited to a maximum of 0.06 . According to the 'no-tillage scenario', soil erosion and sediment input on all cropland in Miyun County could be reduced from 9,272 to $2,620 \mathrm{t} \mathrm{ha}^{-1}$ year $^{-1}$, and 1,029 to $161 \mathrm{t} \mathrm{ha}^{-1}$ year $^{-1}$, respectively (Figure 6).

The mitigation effects of the 'no-tillage' scenario compared with the present state simulation (2009) are presented in Figure 7 for Miyun County. It can be seen that this measure reduces soil erosion on cropland by approximately $63 \%$ and the sediment input by $82 \%$, respectively.

\section{Discussion}

Different studies have been published up to now, which deal with the problems of water quantity and quality in the Miyun catchment area (Ou and Wang 2008; $\mathrm{Xu}$ et al. 2009; Chen et al. 2011a; Ma et al. 2010). Nevertheless, there is a lack of specific regional knowledge of the processes of runoff generation, as well as of sediment and nutrient dynamics. Quantification of water, sediment and nutrient fluxes and identification of relevant processes is difficult and has not yet been accomplished. Ongley et al. (2010) compared methods for non-pointsource estimation developed in the United States regarding their application to the Chinese natural and economic conditions. They postulate, 'Empirical research is limited and does not provide an adequate basis for calibrating

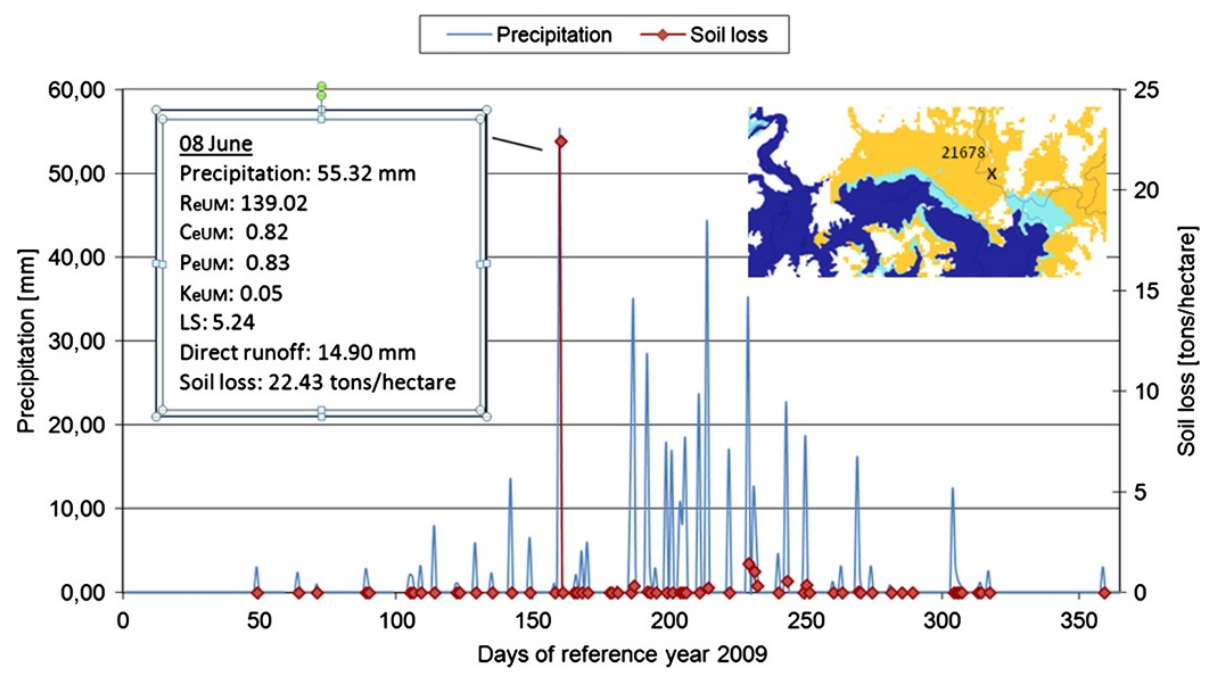

Figure 8 Daily precipitation and simulated soil loss at cell nr. 21678; corn; baseline scenario. 
models...' and, 'The Chinese agricultural situation is so different from that of the United States that empirical data produced in America, as a basis for applying estimation techniques to rural non-point sources in China, often do not apply.' The monitoring results of our project emphasize the necessity to explore and learn from the processes first and then to parameterize the modelling tools, to consider the very regional specific situation of climate, relief and management (Meissner and Hagenau 2013).

Soil erosion as one of the major driving forces for sediment and particulate phosphorus input into the Miyun reservoir has been estimated in different studies based on the USLE over a one-year timescale (Tian et al. 2009; Chen et al. 2011a,b). Limitations of this approach are given by a number of specific regional patterns. First, owing to the extremely high slopes on the rocky ground in large parts of the catchment area, the erosion risks are generally simulated to be very high. Compared with that, the observations on the Wischmeier plots of Shixia station underline that soil erosion by runoff is mostly relevant on cropland with stronger slopes, but of little importance on soils covered with natural or seminatural vegetation. Secondly, cropland terraces are very common in the study area, but normally not included in the elevation model at the mesoscale, which often leads to an overestimation of soil erosion on these sites. Thirdly, water and sediment fluxes in the semiarid monsoon climate are extremely episodic and mostly occur in summer. The dominant crop type is corn, causing an unprotected soil cover in spring and early summer, with a high soil erosion risk. This is demonstrated by a depicted model cell (Figure 8).

\section{Conclusions}

Taking our findings into account, it seems to be necessary that for a reliable simulation a more process-based consideration of rainfall events as well as water and sediment fluxes at a higher time resolution is needed. To fulfil the aforementioned requirements, a daily based USLE-M approach (Kinnell, 2001) was introduced into the modelling of the total catchment area. Combined with a daily based runoff modelling approach (NRCS 2004; Allen et al. 1998) it was possible to simulate the sediment input into surface waters in the same step. The simulation of the baseline scenario shows that critical source areas are particularly located on the former lakebed of the water reservoir, now planted with corn, but also exist in the larger river valleys in all parts of the catchment with corn cropping. Terraced ground as well as forest and shrubs contribute to soil erosion and sediment input to a very low extent; this is confirmed by observations at the Shixia research station. First-decision support was given by a further simulation, considering conservation tillage on cropland in Miyun County.
Nevertheless, the simulations are a rough estimate and only a first step in establishing integrated sediment and water resources management. This is because the availability of spatial and monitoring data (for example, runoff, sediment loads) was particularly limited at the river basin scale, caused by the legal and political framework. Additionally there is insufficient cooperation between the stakeholders of soil, water and agricultural affairs in the different provinces of the catchment area; this seems to be an important obstacle to the establishment of integrated river basin management. Future regulation of runoff and water quality should be managed hand in hand with soil conservation, soil fertility and food production within a more holistic and integrated approach, as fits the idea of the ecosystem services concept (Alcamo et al. 2003).

\section{Abbreviations}

BWA: Beijing Water Authority; SDR: sediment delivery ratio; USLE: Universal Soil Loss Equation; USLE-M: modified Universal Soil Loss Equation.

\section{Competing interests}

The authors declare that they have no competing interests.

\section{Authors' contributions}

MG, MU, and SH jointly carried out the modelling. RM, and SD supervised the project. All authors wrote the manuscript, and read and approved the final manuscript.

\section{Acknowledgements}

This study is funded by the German Federal Ministry of Education and Research (BMBF, FKZ 02WM 1047/1049). We would like to thank all colleagues from the Beijing Water Authority (BWA) and the Soil Conservation Center for their cooperation, support and data on agriculture, hydrology, soil and climate. Stakeholder participation took place in a collaborative project, granted by the Chinese Ministry of Water.

\section{Author details}

Gesellschaft für Angewandte Landschaftsforschung (GALF) bR, Am Ende 14 01277 Dresden, Germany. ${ }^{2}$ Department of Soil Physics, Helmholtz Centre for Environmental Research - UFZ, Lysimeter Station, Dorfstraße 55, 39615 Falkenberg, Germany. ${ }^{3}$ Beijing Soil and Water Conservation Center (BWA), No.5 Yunuantan South Road, Beijing 100038, Haidian District, China.

Received: 17 September 2013 Accepted: 30 January 2014 Published: 18 February 2014

\section{References}

Alcamo J, Ash NJ, Butler CD, Callicot JB, Capistrano D, Carpenter SR (2003) Millennium Ecosystem Assessment - Ecosystems and Human Well-Being: a Framework for Assessment. Island Press, Washington

Allen RG, Pereira LS, Raes D, Smith M (1998) Crop Evapotranspiration - Guidelines for Computing Crop Water Requirements. FAO Irrigation and Drainage Paper No. 56. Food and Agriculture Organization of the United Nations, Rome

Arnoldus JMJ (1977) Methodology used to determine the maximum potential average annual soil loss due to sheet and rill erosion in Morroco. FAO Soils Bull 34:39-51

Cai X (2008) Water stress, water transfer and social equity in Northern China-implications for policy reforms. J Environ Manage 87:14-25

Chen T, Niu RQ, Li PX, Zhang LP, Du B (2011a) Regional soil erosion risk mapping using RUSLE, GIS, and remote sensing: a case study in Miyun Watershed, North China. Environ Earth Sci 63:533-541

Chen T, Niu RQ, Wang Y, Li PX, Zhang LP, Du B (2011 b) Assessment of spatial distribution of soil loss over the upper basin of Miyun reservoir in China based on RS and GIS techniques. Environ Monit Assess 179:605-617 
COST Action 869 (2006) Mitigation Options for Nutrient Reduction in Surface Water and Groundwaters. 164th CSO Meeting 29-30 March 2006. Proposal for a new COST Action. European Cooperation in Science and Technology, Brussels

Dissmeyer GE, Foster GR (1980) A Guide for Predicting Sheet and Rill Erosion on Forest Land. USDA-Forest Service, Southern region, 1720 Peachtree Road, Atlanta, Georgia 30367

EU (2000) Directive 2000/60/EC of the European Parliament and of the Council establishing a framework for the Community action in the field of water policy. Off J Eur Communities L 327:1

FAO/IIASA/ISRIC/ISS-CAS/JRC (2009) Harmonized World Soil Database (version 1.1). Food and Agriculture Organization of the United Nations, Rome, Italy and International Institute for Applied Systems Analysis, Laxenburg, Austria, http://www.fao.org/soils-portal/soil-survey/soil-maps-and-databases/otherglobalsoil-maps-and-databases/en/, Accessed 11 Sept 2013

Gebel M, Halbfass S, Bürger S, Friese H, Naumann S (2010) Modelling of nitrogen turnover and leaching in Saxony. Adv Geosci 27:139-144

Gebel M, Halbfass S, Bürger S, Uhlig M (2012a) STOFFBILANZ - Commentary of the STOFFBILANZ Programme. http://galf-dresden.de/galf/wp-content/ uploads/2013/06/Stoffbilanz_commentary.pdf, Accessed 11 Sept 2013

Gebel M, Halbfass S, Bürger S, Lorz C (2012b) Long-term simulation of effects of energy crop cultivation on nitrogen leaching and surface water quality in Saxony/Germany. Reg Environ Change 13:249-261

Gebel M, Meissner R, Halbfass S, Hagenau J, Duan S (2014) Web GIS-based simulation of water fluxes in the Miyun catchment area. iForest Biogeosci For. in press

Halbfass S (2005) Entwicklung eines GIS-gestützten Modells zur Quantifizierung diffuser Phosphoreinträge in Oberflächengewässer im mittleren Massstab unter Berücksichtigung geoökologisch wirksamer Raumstrukturen. Dresden University of Technology, Dissertation

Halbfass S, Grunewald K (2008) Ermittlung räumlich verteilter Sediment Delivery Ratio zur Modellierung von Sedimenteinträgen in Fliessgewässer im mittleren Massstab. Wasserwirtschaft 3:31-35

Hawkins RH, Ward TJ, Woodward DE, van Mullem JA (2009) Curve Number Hydrology: State of the Practice. American Society of Civil Engineers, Reston, Virginia

Hijmans RJ, Cameron SE, Parra JL, Jones PG, Janvis A (2005) Very high resolution interpolated climate surfaces for global land areas. Int J Climatol 25:1965-1978

Kinnell PIA (2001) The USLE-M and modeling erosion within catchments. In: Stott DE, Steinhardt GC, Sustaining the Global Farm (ed) Selected papers from the 10th International Soil Conservation Organization on Meeting held May 24-29, 1999 at Perdue University and the USDA-ARS National Soil Erosion Research Laboratory. International Soil Conservation Organization, in cooperation with United States Department of Agriculture, Agricultural Research Service, National Soil Erosion Research Laboratory and Purdue University, West Lafayette, IN

Ma H, Yang D, Tan SK, Gao B, Hu Q (2010) Impact of climate variability and human activity on streamflow decrease in the Miyun Reservoir catchment. J Hydrol 389:317-324

Meissner R, Ollesch G, Kröger C, Engelke P, Gebel M, Halbfass S (2011) Catchment-based water management in the Miyun Reservoir - A contribution to safeguarding the drinking water supply of Beijing. KW Korrespondenz Wasserwirtschaft 4(12/11):674-679

Meissner R, Hagenau J (2013) Development and implementation of a scientific based management system for non-point source pollution control in the Miyun basin near Beijing/China. IWRM-Booklet of the BMBF 2013:27-29

NRCS (2004) National Engineering Handbook Part 630 Hydrology - Estimation of Direct Runoff from Storm Rainfall. United States Department of Agriculture. Natural Resources Conservation Service, Washington DC

Ollesch G, Kistner I, Meissner R, Lindenschmidt KE (2006) Modelling of snowmelt erosion and sediment yield in a small mountain catchment. Catena 68:161-176

Ongley ED, Zhang X, Yu T (2010) Current status of agricultural and rural nonpoint source pollution assessment in China. Environ Pollut 158:1159-1168

Ou Y, Wang X (2008) Identification of critical source areas for non-point source pollution in Miyun reservoir watershed near Beijing, China. Water Sci Technol 58(11):2235-2241

Peisert C, Sternfeld E (2004) Quenching Beijing's thirst: the need for integrated management for the endangered Miyun reservoir. China Environ Ser 7:33-45

Renard KG, Freimund JR (1994) Using monthly precipitation data to estimate the $R$-factor in the revised USLE. J Hydrol 157:287-306

SAGA (2013) System for Automated Geoscientific Analyses. http://www.saga-gis. org/en/index.html. Accessed 26 Aug 2013
Tao F, Yokozawa M, Hayashi Y, Lin E (2005) A perspective on water resources in China: interactions between climate change and soil degradation. Clim Change 68:169-197

Tian YC, Zhou YM, Wu BF, Zhou WF (2009) Risk assessment of water soil erosion in upper basin of Miyun Reservoir, Beijing, China. Environ Geol 57:937-942

Veith TL (2002) Agricultural BMP Placement for Cost-Effective Pollution Control at the Watershed Level. Dissertation, Virginia Polytechnic Institute and State University, Blacksburg, Virginia

Voges J (1999) Empirisches Modell für die mittlere Massstabsebene zur GIS-gestützten Bestimmung der Anbindung erosionsgefährdeter Ackerflächen an Fliessgewässer. Dissertation, University of Hannover

Wang X (2006) Managment of agricultural non point source pollution in China: current status and challenges. Water Sci Technol 53(2):1-9

Wischmeier WH, Smith DD (1978) Predicting rainfall losses - a guide to conservation planning. USDA Agric Handb 537:1-58

WorldClim (2013) Global Climate Data. http://www.worldclim.org. Accessed 11 Sep 2013

Xu ZX, Pang JP, Liu CM, Li JY (2009) Assessment of runoff and sediment yield in the Miyun Reservoir catchment by using SWAT model. Hydrol Process 23:3619-3630

Yu B, Rosewell CJ (1996) A robust estimator of the $R$-factor for the universal loss equation. Am Soc Agric Eng 39(2):559-561

Zhou Y, Yang H, Mosler HJ, Abbaspour KC (2010) Affecting farmers' decision on fertilizer use: a case study for the Chaobai watershed in Northern China. J Sustainable Dev 3(1):80-102

doi:10.1186/2192-1709-3-5

Cite this article as: Gebel et al:: Predicting erosion and sediment yield in a mesoscale basin in the semiarid monsoon region Miyun/China. Ecological Processes 2014 3:5.

\section{Submit your manuscript to a SpringerOpen ${ }^{\odot}$ journal and benefit from:}

- Convenient online submission

Rigorous peer review

- Immediate publication on acceptance

- Open access: articles freely available online

- High visibility within the field

- Retaining the copyright to your article

Submit your next manuscript at $>$ springeropen.com 